\title{
Infectivity of Eggs of Taenia taeniaeformis after Anerobic Digestion of Sewage Sludge - A Possible Model for Taenia saginata Egg Resistance
}

Taenia saginata cysticercosis is recognized as a major parasite problem following waste water and waste water sludge application on agricultural land. Thus several reports describe widespread infections in cattle grazing areas where such wastes of human origin are spread (e.g. Richard \& Adolph 1977, Hammerberg et al. 1978, Arundel \& Adolph 1980, Nansen \& Henriksen 1986). Knowledge of the influence of various sewage treatment processes on eggs of $T$. saginata is therefore of interest.

Since testing of infectivity of $T$. saginata eggs in experimental calves is timeconsuming and expensive, a study was designed to evaluate the infectivity of eggs of the closely related $T$.taeniaeformis after anaerobic digestion at mesophilic temperatures. T. taeniaeformis develops cysts in the liver of mice, and it might perhaps offer a feasible experimental alternative to $T$. saginata, provided the 2 species are equally susceptible to the breakdown processes under sewage treatment.

Approximately 1,000 T. taeniaeformis eggs were dispensed in each of a number of plastic sacs (Versapor ${ }^{\circledR}, 3 \mu \mathrm{m}$ ). The sacs were heat sealed. With the exception of 2 zero control sacs, they were immersed into either the sewage sludge content of a mesophilic anaerobic batch digester kept at $35^{\circ} \mathrm{C}$, or for comparison into a bottle containing saline, i.e. $0.85 \% \mathrm{NaCl}$ solution, kept at $4^{\circ} \mathrm{C}$. Sacs were removed from the $35^{\circ} \mathrm{C}$ digester after 2 ,
$5,7,14$ and 28 days, and from the $4^{\circ} \mathrm{C}$ saline container after 28 and 91 days of storage.

Eggs were collected from individual sacs by means of a wash in saline, transferred to a tube, and sedimented by centrifugation at $3000 \mathrm{rpm}$. for $10 \mathrm{~min}$. The supernatant was removed and the eggs were resuspended in a small volume of saline. Based on repeated egg counts 2 egg batches in saline were prepared, containing 200 and 20 eggs per $\mathrm{ml}$, respectively. Infectivity tests were subsequently made by intragastric application of $0.5 \mathrm{ml}$ of each of the egg batches to 6 mice (N-MRI, males, 20-22 g); 6 untreated mice served as control group. The zero control group comprised 12 mice.

The results of the experiments are summarizied in Table 1. At mesophilic anaerobic digestion at $35^{\circ} \mathrm{C}$ the infectivity, expressed as number of cysts in percentage of egg given, declined rapidly from approximately $25 \%$ to approximately $2 \%$ in only 2 days. From the fifth day onwards no cysts were found in livers from this group at post mortem inspections.

At $4^{\circ} \mathrm{C}$ as many as $36 \%$ of the eggs given were recovered as cysts after 28 days, and after 91 days an infectivity of approximately $10 \%$ was recorded. No mice in the zero control group were infected with $T$. taeniaeformis. It was noteworthy, that after both treatments the establishment rate tended to be highest at the lowest dose level throughout. At this dose level, however, the stan- 
Table 1. Infectivity of Taenia taeniaeformis eggs to mice after mesophilic $\left(35^{\circ} \mathrm{C}\right)$ anaerobic digestion in sewage sludge and after storage in saline $\left(4^{\circ} \mathrm{C}\right)$.

\begin{tabular}{|c|c|c|c|c|c|c|c|c|}
\hline \multirow[b]{2}{*}{ Temperature } & \multirow[b]{2}{*}{ Egg-doseS } & \multicolumn{7}{|c|}{$\begin{array}{c}\text { Cysts in percentage of eggs given* } \\
\text { on day }\end{array}$} \\
\hline & & 0 & 2 & 5 & 7 & 14 & 28 & 91 \\
\hline \multirow[t]{5}{*}{$35^{\circ} \mathrm{C}$} & 100 & 21 & 2 & 0 & 0 & 0 & 0 & 0 \\
\hline & SD*: & 7 & 2 & 0 & 0 & 0 & 0 & 0 \\
\hline & 10 & 27 & 3 & 0 & 0 & 0 & 0 & 0 \\
\hline & SD: & 15 & 5 & 0 & 0 & 0 & 0 & 0 \\
\hline & 0 & 0 & 0 & 0 & 0 & 0 & 0 & 0 \\
\hline \multirow[t]{5}{*}{$4^{\circ} \mathrm{C}$} & 100 & 21 & nd. & nd. & nd. & nd. & 29 & 5 \\
\hline & SD: & 4 & - & - & - & - & 13 & 2 \\
\hline & 10 & 58 & nd. & nd. & nd. & nd. & 36 & 16 \\
\hline & SD: & 37 & - & - & - & - & 29 & 15 \\
\hline & 0 & 0 & nd. & nd. & nd. & nd. & 0 & 0 \\
\hline
\end{tabular}

\$: Eggs were given per stomach tube and they were suspended in $0.5 \mathrm{ml}$ of saline $(0.85 \% \mathrm{NaCl})$.

\#: Average of cysts observed in six mice (NRM-I males, 20-22 g).

*: SD: standard deviation. nd.: not done.

dard deviation greatly exceeded that of the 100 eggs dose level.

Microscopical examination revealed that the eggs generally maintained their normal morphological structure long time after infectivity had been lost. Thus at $35^{\circ} \mathrm{C}$, many normal eggs were noticed from day 5 onwards, whereas none of these eggs were able to establish cysts.

The results confirm earlier observations of a very rapid inactivation of Taenia eggs at anaerobic digestion. Sharfi (1982) found that eggs of $T$. taeniaeformis lost infectivity after 9 days at mesophilic digestion, and Silverman \& Guiver (1960) observed that $T$. saginata eggs were no longer infective after 5 days in a $35^{\circ} \mathrm{C}$ anaerobic sludge digester. Newton (1948) has described morphological changes in eggs of $T$. saginata in a $35^{\circ} \mathrm{C}$ anaerobic digester, and the observations made in this study with respect to morpho- logical changes of $T$. taeniaeformis eggs are in good accordance with these results.

In conclusion, mesophilic anaerobic digestion of sewage sludge caused a rapid loss of infectivity of $T$. taeniaeformis eggs. The loss of infectivity significantly preceded that of microscopically apparent changes in the eggs, and the rate of inactivation resembled that previously described for eggs of $T$. saginata. The in vivo testing in mice constitute a simple, cheap and sensitive laboratory procedure. A dose level as low as 10 eggs per mouse may reveal changes in infectivity. Although $T$.taeniaeformis and $T$. saginata are closely related one should compare the susceptibility of their eggs to environmental factors once and for all by infectivity testing in their respective intermediate hosts. This could form the basis for an eventual use of $T$. taeniaeformis as an indicator of T. saginata egg survival. 


\section{Acknowledgement}

This study was supported by the Danish Ministry of Energy affairs (grants No. EFP 22591-82 and EFP 2259-310). The authors wish to thank the Centre of Tropical Veterinary Medicine, University of Edinburgh, Scotland, for providing the $T$. taeniaeformis eggs.

\section{John Elmerdahl Olsen and Peter Nansen}

Department of Veterinary Microbiology,

Royal Veterinary and Agricultural University, Frederiksberg, Denmark.

\section{References}

Arundel JH, Adolph AJ: Preliminary observations on the removal of Taenia saginata eggs from sewage using various treatment processes. Austr. Vet. J. 1980, 56, 492-495.

Hammerberg B, MacInnis GA, Hyler T: Taenia saginata cysticerci in grazing steers in Virginia. J. Amer. vet. med. Assoc. 1978, 173. 1462-1464.

Nansen P, Henriksen SAa: The epidemiology of bovine cysticercosis ( $C$. bovis) in relation to sewage and sludge application on farmland. In:
Epidemiological studies on risks associated with the agricultural use of sewage sludge: Knowledge and needs. Proceedings of an CEC seminar, Metz, France, 1985. Applied Science Publishers 1986, p. 76-82.

Newton WL: Observations on the effect of various sewage treatment processes upon eggs of T. saginata. Amer. J. Hyg. 1949, 49. 166-175. Richard MD. Adolph AJ: The prevalence of cysticerci of Taenia saginata in cattle reared on sewage-irrigated pasture. Med. J. Austr. 1977, 1. 525-527.

Sharfi I: The effect of sewage treatment processes on the viability of Taenia taeniaeformis ova and embryonation of Toxocaris canis and the effect of soil treatment with dried or liquid anaerobically digested sludge on embryonation of Toxocare canis ova. PhD Thesis, University of Illinois, Dissertation Abstract International 1982, 42, 3599B.

Silverman PH, Guiver K: Survival of eggs of Taenia saginata (the human beef tapeworm) after mesophilic anaerobic digestion. J. Inst. Sewage Purific. 1960, 3, 345-347.

(Received April 29. 1990: accepted June 12. 1990).

Reprints may be requested from: Peter Nansen, Department of Veterinary Microbiology, Royal Veterinary and Agricultural University, 13 Bülowsvej, DK-1870 Frederiksberg C, Denmark. 